\title{
MENINGKATKAN MOTIVASI BELAJAR SISWA MELALUI PENDEKATAN PROBLEM BASED LEARNING (PBL) PADA PEMBELAJARAN SEJARAH KEBUDAYAAN ISLAM DI MADRASAH ALIYAH NEGERI 2 MATARAM NUSA TENGGARA BARAT
}

\section{Oleh Lenny Herlina*}

\begin{abstract}
Abstrak: Sejarah Kebudayaan Islam (SKI) merupakan salah satu pelajaran yang diberikan sejak dini dari tingkat Madrasah Ibtidaiyah (MI) sampai Perguruan Tinggi (PT), khususnya Perguruan Tinggi Agama Islam (PTAI). Pada umumnya SKI dirasakan lebih sulit untuk dipahami daripada ilmu-ilmu lainnya. Salah satu penyebabnya adalah karena sejarah mempelajari sesuatu yang sudah terjadi dan tidak dialami oleh siswa, dan tidak adanya kesesuaian antara kemampuan siswa dengan cara penyajian materi. Nuansa kegiatan pembelajaran SKI yang dilaksanakan saat ini di madrasah lebih tampak guru mengajar dibandingkan siswa belajar. Pembelajaran SKI terkesan hanya bersifat hafalan dan normatif saja. Guru SKI dalam pembelajarannya dianggap membosankan siswa sehingga siswa bersikap tak acuh terhadap pelajaran dan berdampak pada kurang maksimalnya hasil belajar. Pendekatan pembelajaran dapat dikatakan sebagai salah satu faktor penentu keberhasilan, dalam pelaksanaannya metode diharapkan dapat menumbuhkan motivasi dan minat belajar siswa guna mencapai tujuan pembelajaran yang diharapkan. Untuk itu perlu diupayakan strategi dan metode yang dapat memotivasi siswa untuk menuntaskan materi dengan baik.
\end{abstract}

Kata Kunci: Motivasi belajar, pendekatan Problem Based Learning, Sejarah Kebudayaan Islam, MAN 2 Mataram

* Dosen MKU Agama Islam di Fakultas Kedokteran Universitas Mataram 


\section{Latar Belakang}

Dendidikan merupakan bagian penting dari hidup dan kehidupan manusia oleh karena kekuatannya sebagai pelestari tata sosial dan tata nilai. Pendidikan pada hakikatnya adalah mencakup kegiatan mendidik, mengajar dan melatih para siswa. Istilah mendidik menunjukkan usaha yang lebih ditujukan pada pengembangan budi pekerti, hati nurani, semangat, kecintaan, rasa kesusilaan, ketakwaan, dan lain-lain. Sedangkan mengajar berarti mentransfer berbagai ilmu yang bermanfaat bagi perkembangan kemampuan intelektual siswa. Sementara istilah melatih, merupakan suatu usaha untuk memberi sejumlah keterampilan tertentu yang dilakukan secara berulang-ulang, sehingga akan terjadi suatu pembiasaan dalam bertindak (Sikun Pribadi, 1971:43).

Menurut Hummel, tujuan pendidikan setidak-tidaknya harus mengandung tiga nilai. Pertama autonomy, yaitu memberi kesadaran, pengetahuan dan kemampuan secara maksimum kepada individu maupun kelompok untuk dapat hidup mandiri dan hidup bersama ke arah kehidupan yang lebih baik. Kedua equity, berarti bahwa tujuan pendidikan tersebut adalah memberi kesempatan kepada seluruh warga masyarakat untuk dapat berpartisipasi dalam kehidupan berbudaya dan kehidupan ekonomi dengan memberinya pendidikan yang baik, berguna dan bermanfaat sebagai sarana dan bekal menuju ke arah itu. Ketiga survival, yang berarti bahwa dengan pendidikan akan menjamin pewarisan budaya dari satu generasi kepada generasi berikutnya (Charles Hummel, 1977:39).

Nilai-nilai di atas menggambarkan pendidikan dalam konteks yang luas, yaitu menyangkut kehidupan seluruh siswa, di mana digambarkan bahwa tujuan pendididkan adalah untuk mencapai kehidupan yang lebih baik. Ini berarti bahwa pendidikan itu tidak hanya suatu ide, tetapi sesuatu yang dibuat ideal.

Dalam kaitan ini, Muchtar Buchori mengemukakan, bahwa pendidikan yang baik dan ideal adalah pendidikan yang mempersiapkan siswa untuk menghadapi tiga tugas kehidupan yaitu: a) untuk dapat hidup (to make a living); b) untuk 
mengembangkan kehidupan yang bermakna (to lead a meaningful live); dan c) untuk turut memuliakan kehidupan (to ennoble life) (Muchtar Buchori, 2001:50). Karakter yang demikian ini, sudah barang tentu, tidak akan terwujudkan tanpa adanya usaha sadar untuk menumbuhkembangkan potensi sumber daya manusia (baca: siswa) dengan cara mendorong dan memfasilitasi kegiatan belajar mengajar mereka (Muhibbin Syah, 2002:1).

Secara detail, dalam Undang-Undang RI Nomor 20 tahun 2003 tentang Sistem Pendidikan Nasional Bab I Pasal (1) Pendidikan didefinisikan sebagai:

Usaha sadar dan terencana untuk menumbuhkan suasana belajar dan proses belajar agar siswa secara aktif mengembangkan potensi dirinya untuk memiliki kekuatan spiritual keagamaan, pengendalian diri, keperibadian, kecerdasan, akhlak mulia, serta keterampilan yang diperlukan dirinya, masyarakat, bangsa, dan negara. (Hasbullah, 2006: 304-395)

Oleh karenanya, untuk mewujudkan apa yang diidealkan sebagaimana yanng diamanatkan oleh UU SISDIKNAS di atas, keahlian seorang guru sangat dituntut, terutama dalam hal penyampaian dan penyajian materi pembelajaran. Hal ini lumrah disebabkan keberadaan guru sebagai pengajar merupakan pencipta kondisi belajar siswa yang didesain secara sengaja, sistematis, dan berkesinambungan. Sedangkan siswa berperan sebagai subjek pembelajaran yang merupakan pihak yang menikmati kondisi belajar yang diciptakan guru. Guru yang profesional adalah guru yang mampu melaksanakan tugas sesuai dengan profesinya, senantiasa dinamis dalam pengembangan kurikulum, fleksibel menerima perubahan serta mampu membangun hubungan dengan lingkungan sekitarnya.

Menurut Wilensky, terdapat lima langkah untuk memprofesionalkan pekerjaan, termasuk bagaimana membangun karakter sebagai Guru profesional, yaitu:

(1) Memunculkan suatu pekerjaan yang penuh waktu, (2) menetapkan sekolah sebagai tempat menjalani proses pendidikan dan pelatihan, (3) mendirikan asosiasi profesi, (4) melakukan agitasi secara politis untuk memperjuangkan adanya perlindungan hukum terhadap asosiasi, (5) 
mengadopsi secara formal kode etik yang ditetapkan. Dengan demikian Guru profesional dalam proses pembelajaran dituntut untuk membuka cakrawala inovatif model pembelajaran terutama mata pelajaran agama yang terkadang dipandang sebelah mata oleh siswa. (Danim, 2002: 28-29)

Secara konseptual, keterlibatan dan tanggungjawab guru dalam proses pembelajaran adalah merancang strategi pembelajaran yang relevan dengan situasi serta kebutuhan siswa. Guru dituntut menentukan dan menerapkan suatu metode pembelajaran yang tepat dengan memanfaatkan kemampuan akademik siswa yang heterogen agar prestasi belajar siswa baik.

Menurut Djamarah dan Surakhmad dalam Fathurrahman, ada lima faktor yang mempengaruhi penggunakan metode mengajar, yakni: (1) Tujuan dengan berbagai jenis dan fungsinya, (2) Anak didik dengan berbagai tingkat kematangannya, (3) Situasi berlainan keadaannya, (4) Fasilitas bervariasi secara kualitas dan kuantitasnya, (5) Kepribadian dan kompetensi guru yang berbeda-beda (Fathurrahman dan Sutikno, 2004:15). Senada dengan hal ini, Suryasubroto mengemukakan lima faktor yang perlu diperhitungkan dalam memilih dan menggunakan metode mengajar: (1) Tujuan yang akan dicapai, (2) Bahan yang akan diberikan, (3) Waktu dan perlengkapan yang tersedia, (4) Kemampuan dan banyaknya murid, dan (5) Kemampuan guru mengajar (Suryasubroto, 1997:160).

Seperti yang terjadi di Madrasah Aliyah Negeri 2 Mataram, ditemukan kompetensi siswa pada mata pelajaran SKI bervariasi. Sebagian siswa tidak responsif terhadap materi sejarah klasikal yang notabene identik dengan hafalan yang hanya menuntut kemampuan ingatan siswa. Siswa rata-rata dalam belajar tanpa dibekali keinginan untuk memahami dan mengetahui materi-materi yang diajarkan oleh guru. sebagian siswa kurang bisa memilah-milah materi sejarah antara dinasti yang satu dengan dinasti yang lain, sehingga tidak sedikit siswa yang keliru dalam menyebutkan dan menjawab soal yang diberikan guru (Observasi, tanggal 06 Agustus 2016). L.G. Widja menjelaskan tentang posisi guru-guru sejarah hanya membeberkan fakta-fakta yang hanya berupa urutan tahun dan 
peristiwa belaka, dengan model dan teknik pembelajaran yang kurang berkembang dan mengabaikan keterlibatan siswa, sehingga kurang begitu menyentuh diri siswa dan lingkungannya dalam kehidupan mereka yang sesungguhnya (Widja, 1989: 23).

Pengembangan kurikulum mengacu kepada siswa sebagai pusat sumber belajar, Sehingga dalam strategi pembelajaran agama diharapkan siswa dapat menguasai konsep atau materi secara proporsional. Berdasarkan permasalahan tersebut dalam penelitian ini dicobakan metode pembelajaran lain yang dapat memanfaatkan kemampuan akademik siswa yang heterogen yaitu pembelajaran berbasis masalah (problem based learning).

Problem Based Learning (PBL) merupakan salah satu pendekatan yang dapat digunakan untuk meningkatkan hasil belajar (kognitif, afektif, dan psikomotor) dan kemampuan berfikir tingkat tinggi. Khusus kemampuan berfikir tingkat tinggi selama ini belum ditangani dengan baik. PBL merupakan salah satu pendekatan konstektual (Contextual Teaching and Learning atau disingkat CTL). Pendekatan ini merupakan konsep belajar yang dapat membantu guru mengaitkan antara materi yang diajarkannya dengan situasi dunia nyata siswa serta mendorong siswa membuat hubungan antara pengetahuan yang dimiliki dengan penerapannya dalam kehidupan mereka sebagai anggota keluarga dan masyarakat dengan memunculkan problem yang dihadapi bersama, di mana siswa ditantang untuk berfikir kritis untuk memecahkannya dan akan membawa makna personal dan sosial bagi siswa (Johnson, 2006: 21).

Problem Based Learning (PBL) dikembangkan untuk membantu siswa mengembangkan kemampuan berpikir, memecahkan masalah, dan keterampilan intelektual serta memberikan kesempatan belajar berbagai peran orang dewasa melalui pelibatan mereka dalam pengalaman nyata atau simulasi serta menjadi siswa yang mandiri (self directed learning) (Amir, 2009: 22). Dengan konsep yang penulis tawarkan ini hasil belajar (dimensi kognitif dan afektif) siswa dapat berkembang lebih optimal. Proses pembelajaran berlangsung alamiah berpusat pada siswa (centred of student) dan 
peran guru lebih banyak berurusan dengan strategi daripada memberikan informasi.

\section{Pembahasan}

Peningkatan Ranah Kognitif Melalui Pendekatan Problem Based Learning Di MAN 2 Mataram

Ranah kognitif adalah ranah yang sangat penting dalam sasaran pencapaian tujuan pembelajaran. Karena ranah kognitif merupakan pangkal dari ranah afektif dan psikomotorik. Oleh karena itu, pendidikan dan pembelajaran perlu diupayakan secara maksimal agar ranah kognitif siswa dapat berfungsi secara optimal. Ranah kognitif, sebagaimana yang dikelompokkan Bloom, memiliki 6 (enam) tingkatan, yang disebut taksonomi kognitif yang meliputi: pengetahuan (knowledge); pemahaman (comprehension); penerapan (aplication); analisis (analyshis); sintetis (synthestis); dan menilai (evaluation) (Purwanto, 2006: 46-48). Dalam penelitian ini, peningkatan ranah kognitif siswa diukur melalui perolehan hasil observasi aktivitas siswa pada proses PBL, dan hasil tes (ulangan harian) siswa yang dilakukan pada pertemuan terakhir tiap-tiap siklus.

Hasil Observasi aktivitas kognitif siswa pada proses PBL

Komponen penilaian pelaksanaan proses PBL, sebagaimana yang telah dipaparkan pada bab IV meliputi: a) begerak dengan cepat menuju tempat kelompoknya; b) mendengarkan/memperhatikan penjelasan guru atau teman; c) membaca dan menulis yang relevan dengan kegiatan belajar mengajar; d) mengidentifikasi masalah; e) menganalisis masalah; f) merumuskan tujuan pembelajaran; g) mendiskusikan pertanyaan guru; h) menyampaikan pendapat; i) bertanya antar siswa atau guru; j) menjawab pertanyaan; k) mengerjakan tugas kelompok; dan 1) merangkum materi pelajaran. Komponen penilaian di atas dalam pembahasan ini, tidak semua dimasukkan dalam ranah kognitif (walaupun semua komponen di atas berpangkal pada kemampuan 
kognitif). Ada beberapa komponen yang dikategorikan ke dalam ranah kognitif, yakni: (1) Mengidentifikasi masalah, (2) Menganalisis masalah, (3) Merumuskan tujuan pembelajaran, (4) Menjawab pertanyaan, dan (5) Menyampaikan pendapat.

Identifikasi masalah merupakan keterampilan berpikir yang menuntut siswa untuk tidak saja mengingat kembali (recall atau knowledge) apa yang sudah diketahui tetapi juga dituntut untuk mengenal dan memetakan konsep-konsep baru yang belum dan harus diketahui kemudian di analisis. Analisis masalah menuntut siswa untuk memilah-milah satu topik masalah sampai kepada kemungkinan-kemungkinan terkecil yang terjadi, selanjutnya dipertimbangkan dan dipelajari kembali apakah penting untuk diteruskan sebagai tujuan pembelajaran.

Merumuskan tujuan pembelajaran merupakan keterampilan yang menuntut pengetahuan dan pemahaman serta estimasiestimasi yang kuat, sehingga tujuan yang dirumuskan mampu menjawab masalah yang dituju.

Menjawab pertanyaan menuntut kemampuan ingatan sekaligus analisis siswa dengan pengetahuan dan informasi-informasi baru. Demikian juga menyampaikan pendapat menuntut keterampilan siswa dalam mengolah pengetahuan; mengombinasikan pengetahuan baru dan pengetahuan yang diperoleh sebelumnya menjadi satu kesatuan dan menjadi formulasi baru.

Dalam pelaksanaan pembelajaran berbasis masalah atau PBL, terdapat perubahan-perubahan positif pada ranah kogniti, sebagaimana yang telah dipaparkan pada bab IV, bahwa pembelajaran SKI materi kepemimpinan pasca Rasulullah SAW wafat, melalui pendekatan PBL dapat dikatakan baik, dan memuaskan. Ini diindikasikan dengan perubahan positif pada aktivitas siswa berikut: siklus I siswa lemah dalam mengidentifikasi masalah, menganalisis masalah dan merumuskan tujuan pembelajaran, hal ini terjadi karena pembelajaran berbasis masalah atau PBL adalah hal yang baru diterapkan kepada siswa. Tetapi, pada siklus selanjutnya, siswa dapat meningkatkan kemampuannya pada komponen tersebut. Begitu pula pada komponen 
menyampaikan pendapat, dan kemampuan menjawab pertanyaan dilakukan dengan sempurna oleh para siswa kelas XII IPA Unggulan pada siklus II. Peningkatan ranah konitif siswa disajikan dalam tabel 5.1 berikut:

\section{Tabel. 1}

\section{Rekap Hasil Observasi Aktivitas Siswa Pada Ranah Kognitif}

\begin{tabular}{|c|c|c|c|}
\hline No. & Komponen kognitif & Siklus I & Siklus II \\
\hline & Mengidentifikasi masalah & $\mathrm{C}$ & B \\
\hline 2. & Menganalisis masalah & $\mathrm{C}$ & B \\
\hline 3. & Merumuskan tujuan pembelajaran & $\mathrm{C}$ & A \\
\hline 4. & Menyampaikan pendapat & B & A \\
\hline & Menjawab pertanyaan & B & A \\
\hline & Nilai Rata-rata & 2,4 & 3,6 \\
\hline
\end{tabular}

Keterangan: Skor Maksimal $4=100$

Data di atas menggunakan nilai 4 untuk skor nilai maksimal. Pada siklus I data hasil observasi aktivitas siswa di atas memperoleh nilai rata-rata 2,4 (sama dengan nilai 60 untuk penggunaan nilai skor maksimal 100) dengan kriteria cukup, dan pada siklus II meningkat menjadi 3,6 (sama dengan 90 untuk skor 100) dengan kriteria sangat baik. Dengan demikian, peningkatan ranah kognitif yang ditunjukkan dengan perolehan hasil observasi aktivitas siswa meningkat sampai 30\%.

Perolehan tes hasil belajar (ulangan harian) siswa

Untuk mengetahui apakah ada tidaknya peningkatan ranah kognitif siswa dalam pelaksanaan pembelajaran SKI kelas XII melalui pendekatan PBL, maka akan diperbandingkan antara hasil tes sebelum pelaksanaan PBL (pretest) dengan nilai hasil belajar pada siklus I dan II pelaksanaan PBL.

Pemberian soal tes awal (pretest) pada tanggal 02 Agustus 2010, dilakukan untuk mengukur kemampuan awal siswa terhadap penguasan mata pelajaran SKI materi kepemimpinan umat Islam pasca Nabi wafat. Pada saat pemberian tes siswa telah menempuh pelajaran model pemilihan kepemimpinan umat Islam era al- 
Khulafa' al-Rasyidin. Melalui tes tersebut diperoleh hasil tes siswa mencapai rata-rata 80,6 dengan ketuntasan klasikal 90,3. Hasil belajar siswa melalui ulangan harian pada siklus I pelaksanaan PBL sebagaimana yang yang dipaparkan pada bab sebelumnya mencapai nilai rata-rata 80,8 dengan ketuntasan klasikal 93,5, nilai tertinggi 88 dan nilai terendah 67. Dari hasil tes tersebut 29 dari 31 orang siswa mencapai di atas nilai 70 (standar KKM) dan hanya 2 orang siswa yang tidak mencapai standar KKM.

Pada siklus II pelaksanaan PBL menunjukkan hasil yang memuaskan. Dari hasil tes tersebut 100\% siswa mencapai standar KKM, dengan nilai terendah 86 dan nilai tertinggi 98, nilai rata-rata kelas 92,6 nilai tersebut hanya 5 orang siswa yang memperoleh nilai dibawah 90. Data rekap hasil evaluasi belajar siswa dapat dilihat pada tabel 5.2 dan data rekap ketuntasan belajar siswa pada tabel 5.3 berikut:

Tabel 2

Data Rekap Hasil Tes Belajar Siswa

\begin{tabular}{clcccccc}
\hline \multirow{2}{*}{ No. } & \multirow{2}{*}{ Nama Kode } & \multicolumn{2}{c}{ Pretes } & \multicolumn{2}{c}{ siklus I } & \multicolumn{2}{c}{ Siklus II } \\
& & $\mathbf{N}$ & Ket. & $\mathbf{N}$ & Ket. & $\mathbf{N}$ & Ket. \\
\hline 1 & AF & 85 & $\mathrm{~T}$ & 82 & $\mathrm{~T}$ & 96 & $\mathrm{~T}$ \\
2 & AT & 75 & $\mathrm{~T}$ & 78 & $\mathrm{~T}$ & 90 & $\mathrm{~T}$ \\
3 & AFW & 77 & $\mathrm{~T}$ & 77 & $\mathrm{~T}$ & 88 & $\mathrm{~T}$ \\
4 & AUK & 75 & $\mathrm{~T}$ & 80 & $\mathrm{~T}$ & 94 & $\mathrm{~T}$ \\
5 & DS & 80 & $\mathrm{~T}$ & 80 & $\mathrm{~T}$ & 92 & $\mathrm{~T}$ \\
6 & DDAP & 85 & $\mathrm{~T}$ & 82 & $\mathrm{~T}$ & 94 & $\mathrm{~T}$ \\
7 & DAL & 82 & $\mathrm{~T}$ & 82 & $\mathrm{~T}$ & 94 & $\mathrm{~T}$ \\
8 & DM & 85 & $\mathrm{~T}$ & 80 & $\mathrm{~T}$ & 90 & $\mathrm{~T}$ \\
9 & EL & 82 & $\mathrm{~T}$ & 82 & $\mathrm{~T}$ & 92 & $\mathrm{~T}$ \\
10 & FH & 84 & $\mathrm{~T}$ & 84 & $\mathrm{~T}$ & 92 & $\mathrm{~T}$ \\
11 & Hd & 85 & $\mathrm{~T}$ & 84 & $\mathrm{~T}$ & 94 & $\mathrm{~T}$ \\
12 & Ho & 84 & $\mathrm{~T}$ & 84 & $\mathrm{~T}$ & 94 & $\mathrm{~T}$ \\
13 & IFK & 86 & $\mathrm{~T}$ & 86 & $\mathrm{~T}$ & 94 & $\mathrm{~T}$ \\
14 & IPP & 86 & $\mathrm{~T}$ & 86 & $\mathrm{~T}$ & 96 & $\mathrm{~T}$ \\
15 & Irni & 80 & $\mathrm{~T}$ & 80 & $\mathrm{~T}$ & 96 & $\mathrm{~T}$ \\
16 & Kh & 80 & $\mathrm{~T}$ & 80 & $\mathrm{~T}$ & 90 & $\mathrm{~T}$ \\
\hline
\end{tabular}




\begin{tabular}{|c|c|c|c|c|c|c|c|}
\hline \multirow{2}{*}{ No. } & \multirow{2}{*}{ Nama Kode } & \multicolumn{2}{|c|}{ Pretes } & \multicolumn{2}{|c|}{ siklus I } & \multicolumn{2}{|c|}{ Siklus II } \\
\hline & & $\mathbf{N}$ & Ket. & $\mathbf{N}$ & Ket. & $\mathbf{N}$ & Ket. \\
\hline 17 & $\mathrm{Ki}$ & 82 & $\mathrm{~T}$ & 82 & $\mathrm{~T}$ & 90 & $\mathrm{~T}$ \\
\hline 18 & LH & 80 & $\mathrm{~T}$ & 80 & $\mathrm{~T}$ & 92 & $\mathrm{~T}$ \\
\hline 19 & LS & 70 & TT & 69 & TT & 88 & $\mathrm{~T}$ \\
\hline 20 & MZI & 75 & $\mathrm{~T}$ & 75 & $\mathrm{~T}$ & 88 & $\mathrm{~T}$ \\
\hline 21 & Muth & 80 & $\mathrm{~T}$ & 80 & $\mathrm{~T}$ & 94 & $\mathrm{~T}$ \\
\hline 22 & NS & 67 & TT & 67 & $\mathrm{TT}$ & 94 & $\mathrm{~T}$ \\
\hline 23 & NFW & 86 & $\mathrm{~T}$ & 86 & $\mathrm{~T}$ & 98 & $\mathrm{~T}$ \\
\hline 24 & NDJ & 67 & TT & 80 & $\mathrm{~T}$ & 94 & $\mathrm{~T}$ \\
\hline 25 & NFh & 88 & $\mathrm{~T}$ & 88 & $\mathrm{~T}$ & 96 & $\mathrm{~T}$ \\
\hline 26 & $\mathrm{NLi}$ & 88 & $\mathrm{~T}$ & 88 & $\mathrm{~T}$ & 94 & $\mathrm{~T}$ \\
\hline 27 & $\mathrm{RVi}$ & 86 & $\mathrm{~T}$ & 86 & $\mathrm{~T}$ & 98 & $\mathrm{~T}$ \\
\hline 28 & SKAM & 80 & $\mathrm{~T}$ & 80 & $\mathrm{~T}$ & 94 & $\mathrm{~T}$ \\
\hline 29 & $\mathrm{SZi}$ & 78 & $\mathrm{~T}$ & 78 & $\mathrm{~T}$ & 86 & $\mathrm{~T}$ \\
\hline 30 & WKi & 78 & $\mathrm{~T}$ & 78 & $\mathrm{~T}$ & 88 & $\mathrm{~T}$ \\
\hline 31 & WHAi & 84 & $\mathrm{~T}$ & 80 & $\mathrm{~T}$ & 92 & $\mathrm{~T}$ \\
\hline \multicolumn{2}{|c|}{ Nilai Rata-Rata Kelas } & 80,6 & & 80,8 & & 92,6 & \\
\hline
\end{tabular}

Tabel 3

Data Rekap Ketuntasan Belajar Siswa Pada Mata Pelajaran SKI

\begin{tabular}{clccc}
\hline No. & \multicolumn{1}{c}{ Karakteristik } & Pretest & Siklus I & Siklus II \\
\hline 1 & Jumlah siswa & 31 & 31 & 31 \\
2 & Jumlah siswa yang tuntas & 28 & 29 & 31 \\
3 & Jumlah siswa yang tidak tuntas & 3 & 2 & 0 \\
4 & Ketuntasan klasikal & 90,3 & 93,5 & 100,0 \\
\hline
\end{tabular}

Berdasarkan data di atas, sebelum pelaksanaan PBL hasil belajar melalui pretest rata-rata kelas mencapai 80,6 dengan ketuntasan klasikal 90,3\%, setelah pelaksanaan PBL siklus I nilai rata-rata kelas mencapai 80,8 dengan ketuntasan klasikal 93,5\% dan pada siklus II nilai rata-rata kelas mencapai 92,6 dengan ketuntasan klasikal 100\%. Dengan demikian, peningkatan ranah kognitif yang ditunjukkan dengan perolehan tes hasil belajar siswa mencapai $12 \%$. 
Peningkatan Ranah Afektif Melalui Pendekatan Problem Based Learning di MAN 2 Mataram

Belajar secara umum didefiniksan sebagai proses perubahan perilaku atau perubahan. Perlaku atau perbuatan seseorang ditentukan oleh watak dirinya dan kondisi lingkungan sekitarnya. Sebagaimana Lewin, perilaku seseorang merupakan fungsi dari watak (kognitif, afektif, dan psikomotor) dan karakteristik lingkungan saat perilaku atau perbuatan ditampilkan. Pembelajaran tanpa menyentuh ke tiga ranah (kognitif, afektif dan psikomotorik) tersebut hanya akan melahirkan manusia (generasi) pincang. Oleh karenanya, dalam pelaksanaan pembelajaran penting untuk diperhatikan perkembangan kognitif, afektif dan psikomotorik siswa (Andersen, dalam Depdiknas, 2008).

Pada hakekatnya, penilaian ranah afektif merupakan penilaian yang sulit untuk dirumuskan. Tetapi ranah afektif (daya rasa) ditumbuhkan melalui pemberdayaan sikap siswa dalam menyikapi fenomena yang ada disekitar. Hal ini dikarenakan oleh karakteristik ranah rasa yang lebih bersifat abstrak dan tertutup (meliputi perasaan dan emosi).

Untuk mengukur ranah afektif, menurut Andersen dalam Depdiknas (2008: 34) ada dua metode yang dapat digunakan, yaitu metode observasi dan metode laporan diri. Penggunaan metode observasi berdasarkan pada asumsi bahwa karateristik afektif dapat dilihat dari perilaku atau perbuatan yang ditampilkan dan/atau reaksi psikologi. Metode laporan diri berasumsi bahwa yang mengetahui keadaan afektif seseorang adalah dirinya sendiri. Namun hal ini menuntut kejujuran dalam mengungkap karakteristik afektif diri sendiri.

Dalam penelitian ini, peningkatan ranah kognitif siswa diukur melalui perolehan hasil pengamatan aktivitas afektif siswa dalam proses PBL dengan metode observasi, dan hasil angket umpan balik siswa yang dilakukan pada pertemuan terakhir tiap-tiap siklus. 
Hasil pengamatan aktivitas afektif siswa dalam proses PBL

Komponen penilaian pelaksanaan proses PBL yang meliputi: a) begerak dengan cepat menuju tempat kelompoknya; b) mendengarkan/memperhatikan penjelasan Guru atau teman; c) membaca dan menulis yang relevan dengan kegiatan belajar mengajar; d) mengidentifikasi masalah; e) menganalisis masalah; f) merumuskan tujuan pembelajaran; g) mendiskusikan pertanyaan Guru; h) menyampaikan pendapat; i) bertanya antar siswa atau Guru; j) menjawab pertanyaan; k) mengerjakan tugas kelompok; dan l) merangkum materi pelajaran

Dari 12 (duabelas) komponen penilaian di atas, ada beberapa komponen yang dikategorikan ke dalam ranah afektif, yakni:(1) Bergerak dengan cepat menuju tempat kelompoknya; (2)Mendengarkan/memperhatikan penjelasan Guru atau teman;(3) Membaca dan menulis yang relevan dengan kegiatan belajar mengajar;(4) Mendiskusikan pertanyaan Guru;(5)Bertanya antar siswa atau Guru; (6)Mengerjakan tugas kelompok; dan (7) Merangkum materi pelajaran.

Tujuh item pengamatan di atas merupakan komponenkomponen aktivitas siswa yang berpangkal dan bermuara muara pada ranah aktualisasi nilai, penerapan konsep, dan karakterisasi diri yang menunjukkan keadaan psikis (afektif) siswa dalam berinteraksi (merespon pembelajaran).

Perkembangan aktivitas afektif siswa melalui pendekatan PBL pada mata pelajaran SKI berdasarkan tujuh item pengamatan di atas dapat dikatakan amat baik. Siswa bergerak dengan cepat menuju tempat kelompoknya pada siklus I dan II memperoleh nilai 3, kategori baik. Dalam aktivitas mendengar/memperhatikan penjelasan guru atau teman, membaca dan menulis yang relevan dengan kegiatan belajar mengajar, mendiskusikan pertanyaan guru, bertanya antar siswa atau guru, dan aktivitas siswa dalam mengerjakan tugas kelompok pada siklus I memperoleh nilai 3 (kategori baik) dan pada siklus II meningkat menjadi sangat baik dengan perolehan nilai 4 pada masing-masing item tersebut. Dan pada item merangkum materi pelajaran pada siklus I memperoleh 
nilai 2 dengan katagori cukup kemudian meningkat menjadi sangat baik pada siklus II dengan perolehan nilai 4 (sangat baik). Data rekap hasil observasi aktivitas dapat dilihat pada tabel 5.4 berikut:

\section{Tabel 4}

\section{Rekap Hasil Observasi Aktivitas Siswa Pada Ranah Afektif}

\begin{tabular}{|c|c|c|c|c|c|}
\hline No. & Aktivitas siswa & \multicolumn{2}{|c|}{ Siklus I } & \multicolumn{2}{|c|}{ Siklus II } \\
\hline 1 & $\begin{array}{l}\text { Begerak dengan cepat menuju tempat } \\
\text { kelompoknya }\end{array}$ & B & 3 & B & 3 \\
\hline 2 & $\begin{array}{l}\text { Mendengarkan / memperhatikan } \\
\text { penjelasan Guru atau teman }\end{array}$ & B & 3 & A & 4 \\
\hline 3 & $\begin{array}{l}\text { Membaca dan menulis yang relevan } \\
\text { dengan kegiatan belajar mengajar }\end{array}$ & B & 3 & A & 4 \\
\hline 4 & Mendiskusikan pertanyaan guru & B & 3 & A & 4 \\
\hline 5 & Bertanya antar siswa atau guru & B & 3 & A & 4 \\
\hline 6 & Mengerjakan tugas kelompok & B & 3 & A & 4 \\
\hline 7 & Merangkum materi pelajaran & $\mathrm{C}$ & 2 & A & 4 \\
\hline \multicolumn{3}{|c|}{ Jumlah Nilai } & 20 & & 27 \\
\hline \multicolumn{3}{|c|}{ Nilai Rata-rata } & 2,9 & & 3,9 \\
\hline
\end{tabular}

Pada siklus I data hasil observasi aktivitas siswa di atas memperoleh nilai rata-rata 2,9 (sama dengan nilai 72,5 untuk penggunaan nilai skor maksimal 100) dengan kriteria cukup, dan pada siklus II meningkat menjadi 3,9 (sama dengan 97,5 untuk skor 100) dengan kriteria sangat baik. Dengan demikian, peningkatan ranah afektif yang ditunjukkan dengan perolehan hasil observasi aktivitas siswa meningkat sampai 25\%.

\section{Penilaian pada angket respon siswa}

Untuk mengukur seberapa besar peningkatan ranah afektif siswa maka akan diperbandingkan data analisis respon belajar siswa melalui angket kejenuhan belajar sebelum melakukan PBL dengan angket respon siswa setelah pelaksanaan PBL pada masing-masing siklus.

Berdasarkan analisis angket kejenuhan belajar siswa, sebagaimana dipaparkan pada bab III, tingkat kejenuhan belajar 
siswa pada mata pelajaran SKI dari 31 orang responden terdapat $27,4 \%$ sangat jenuh, 26,7\% jenuh, 18,9\% tidak jenuh, dan $27 \%$ sangat tidak jenuh. Porsentase tersebut kemudian di sederhanakan lagi menjadi dua kategori yakni kategori jenuh 54,1\% dan 45,9\% tidak jenuh. Dengan demikian tingkat kegemaran (motivasi) siswa belajar SKI hanya mencapai 45,9\%.

Data angket respon siswa terhadap pelaksanaan PBL siklus I menunjukkan bahwa 56,5\% dan pada siklus II meningkat menjadi 94,8\% menyukai pembelajaran SKI melalui pendekatan Problem based learning (PBL). Secara detail data respon siswa terhadap pelaksanaan PBL siklus I dan II dapat dilihat pada tabel berikut:

\section{Tabel 5}

Data Respon Siswa Terhadap Pelaksanaan PBL Siklus I dan II

\begin{tabular}{|c|c|c|c|c|c|}
\hline \multirow[b]{2}{*}{ No. } & \multirow[b]{2}{*}{ Uraian } & \multicolumn{2}{|c|}{ Siklus I } & \multicolumn{2}{|c|}{ Siklus II } \\
\hline & & $\begin{array}{c}\text { Senang } \\
(\%)\end{array}$ & $\begin{array}{c}\text { Tidak } \\
\text { Senang } \\
(\%)\end{array}$ & $\begin{array}{l}\text { Senang } \\
(\%)\end{array}$ & $\begin{array}{l}\text { Tidak } \\
\text { Senang } \\
(\%)\end{array}$ \\
\hline 1 & $\begin{array}{l}\text { Bagaimana perasaan anda selama } \\
\text { mengikuti proses PBL ini? }\end{array}$ & 55 & 45 & 90 & 10 \\
\hline 2 & $\begin{array}{l}\text { Bagaimana perasaan anda } \\
\text { terhadap suasana belajar di kelas } \\
\text { selama proses pelaksanaan PBL? }\end{array}$ & 61 & 39 & 94 & 6 \\
\hline 3 & $\begin{array}{l}\text { Bagaimana menurut anda } \\
\text { terhadap kegiatan } \\
\text { mengidentifikasi masalah dalam } \\
\text { pembelajaran SKI dilakukan } \\
\text { dengan pola PBL? }\end{array}$ & 48 & 52 & 94 & 6 \\
\hline 4 & $\begin{array}{l}\text { Bagaimana menurut anda } \\
\text { terhadap kegiatan merumuskan } \\
\text { masalah dalam pembelajaran } \\
\text { SKI dilakukan dengan pola PBL? }\end{array}$ & 45 & 55 & 97 & 3 \\
\hline 5 & $\begin{array}{l}\text { Bagaimana menurut anda } \\
\text { terhadap kegiatan menemukan } \\
\text { tujuan pembelajaran dalam } \\
\text { pembelajaran SKI dengan pola } \\
\text { PBL? }\end{array}$ & 52 & 48 & 97 & 3 \\
\hline 6 & $\begin{array}{l}\text { Bagaimana menurut anda } \\
\text { presentasi laporan dalam PBL? }\end{array}$ & 65 & 35 & 100 & 0 \\
\hline
\end{tabular}




\begin{tabular}{llcccc}
\hline & & \multicolumn{2}{c}{ Siklus I } & \multicolumn{2}{c}{ Siklus II } \\
No. & Uraian & $\begin{array}{c}\text { Senang } \\
\mathbf{( \% )}\end{array}$ & $\begin{array}{c}\text { Tidak } \\
\text { Senang } \\
\mathbf{( \% )}\end{array}$ & $\begin{array}{c}\text { Senang } \\
\mathbf{( \% )}\end{array}$ & $\begin{array}{c}\text { Tidak } \\
\text { Senang } \\
\mathbf{( \% )}\end{array}$ \\
\hline 7 & $\begin{array}{l}\text { Bagaimana menurut anda } \\
\text { terhadap penyampaian materi ini } \\
\text { dengan pendekatan PBL? }\end{array}$ & 52 & 48 & 94 & 6 \\
8 & $\begin{array}{l}\text { Bagaimana pendapat anda jika } \\
\text { pokok bahasan selanjutnya } \\
\text { menggunakan pambelajaran } \\
\text { seperti ini? }\end{array}$ & 74 & 26 & 94 & 6 \\
\hline
\end{tabular}

Tingkat kegemaran (motivasi) siswa belajar SKI sebelum menerapkan PBL hanya mencapai 45,9\%, setelah pelaksanaan PBL siklus I respon siswa terhadap pembelajaran SKI sebesar 56,5\% dan pada siklus II meningkat menjadi 94,8\% menyukai pembelajaran SKI melalui pendekatan Problem based learning (PBL). Data peningkatan ranah afektif siswa pada pembelajaran SKI melalui pendekatan PBL dapat dilihat pada tabel berikut:

\section{Tabel 6}

Analisis peningkatan ranah afektif siswa Pada Mata Pelajaran SKI Melalui pendekatan PBL

\begin{tabular}{clc}
\hline No. & \multicolumn{1}{c}{ Respon Siswa } & Prosentase \\
\hline 1 & $\begin{array}{l}\text { Tingkat penerimaan siswa melalui angket } \\
\text { kejenuhan belajar }\end{array}$ & 45,9 \\
2 & Tingkat penerimaan siswa pada siklus I & 56,5 \\
3 & Tingkat penerimaan siswa pada siklus II & 94,8 \\
4 & $\begin{array}{l}\text { Peningkatan ranah afektif siswa setelah } \\
\text { pelaksanaan PBL siklus I }\end{array}$ & 10,6 \\
5 & $\begin{array}{l}\text { Peningkatan ranah afektif siswa setelah } \\
\text { pelaksanaan PBL siklus II }\end{array}$ & 38,3 \\
\hline
\end{tabular}


Data analisis peningkatan ranah afektif, sebagaimana tertera pada tabel di atas menunjukkan bahwa, setelah pelaksanaan siklus I meningkat sebesar 10,6\% dan pada siklus mengalami peningkatan sebesar 38,3\%.

\section{Catatan Akhir}

Berdasarkan temuan data dan pembahasan hasil penelitian yang telah dipaparkan di atas, sesuai dengan fokus masalah yang diteliti, maka dapat disimpulkan sebagai berikut:

Pembelajaran Sejarah Kebudayaan Islam menjenuhkan bagi siswa kelas XII IPA Unggulan di Madrasah Aliyah Negeri 2 Mataram Nusa Tenggara Barat, hal tersebut disebabkan oleh faktor internal dan eksternal siswa. Faktor internal berkaitan erat dengan minat, bakat dan kemampuan intelegensia siswa. Sedangkan faktor eksternal berkaitan dengan muatan materi Sejarah Kebudayaan Islam yang kesannya banyak menggunakan istilah yang rumit dan sulit dipahami oleh siswa; metode dan strategi pembelajaran yang monoton; serta lingkungan belajar yang kadang kurang kondusif.

Fakta tersebut terlihat dari analisis respon belajar siswa pada mata Pelajaran Sejarah Kebudayaan Islam berdasarkan angket kejenuhan, dimana $54,1 \%$ siswa jenuh dan $45,9 \%$ siswa tidak jenuh.

Pembelajaran Sejarah Kebudayaan Islam dengan menerapkan pendekatan Problem Based Learning (PBL) dapat dijadikan alternatif pilihan untuk menanggulangi kejenuhan belajar siswa. Respon siswa terhadap pembelajaran SKI dengan menggunakan pendekatan PBL pada siklus I masih dikatakan berimbang 56\% siswa senang dan 44\% siswa tidak senang. Namun, pada siklus II, 95\% siswa senang dan hanya $5 \%$ yang tidak senang terhadap proses pembelajaran tersebut.

Pendekatan Problem Based Learning (PBL) yang diterapkan pada mata pelajaran SKI kelas XII di MAN 2 Mataram NTB dapat meningkatkan ranah kognitif dan afektif siswa. Peningkatan ranah kognitif yang ditunjukkan dengan perolehan tes hasil belajar siswa mencapai 12\%. Sebelum pelaksanaan PBL hasil belajar melalui pretest nilai rata-rata kelas siswa mencapai 80,6 dengan ketuntasan 
klasikal 90,3\%, setelah pelaksanaan PBL siklus I nilai rata-rata kelas mencapai 80,8 dengan ketuntasan klasikal 93,5\% dan pada siklus II nilai rata-rata kelas mencapai 92,6 dengan ketuntasan klasikal 100\%. Peningkatan ranah kognitif yang ditunjukkan dengan perolehan hasil observasi aktivitas siswa meningkat sampai 30\%. Pada siklus I hasil observasi aktivitas siswa memperoleh nilai rata-rata 2,4 (60) dengan kriteria cukup, dan pada siklus II meningkat menjadi 3,9 (90) dengan kriteria sangat baik.

Peningkatan ranah afektif yang ditunjukkan dengan respon (penerimaan) siswa terhadap pelaksanaan PBL mencapai 48\%. Sebelum penerapan PBL, siswa kurang responsif terhadap pelajaran SKI. Ini ditunjukkan dengan angket kejenuhan belajar siswa pada mata pelajaran SKI 54\% siswa jenuh yang berarti juga hanya $46 \%$ siswa yang merespon positif pembelajaran tersebut. Setelah pelaksanaan PBL, pada siklus I peningkatan ranah afektif siswa membaik, melalui angket umpan balik siswa terhadap pelaksanaan PBL 56,5\% siswa menyukai pelajaran SKI. Dan pada pada siklus II respon siswa berkembang sangat baik, $94,8 \%$ siswa menyukai pembelajaran SKI.

Peningkatan ranah afektif yang ditunjukkan dengan perolehan hasil observasi sikap dan keaktifan siswa dalam pelaksanaan pembelajaran mencapai 25\%. Pada siklus I mendapat nilai rata-rata 2,9 (72,5) dengan kriteria baik dan pada siklus II memperoleh nilai 3,9 $(97,5)$ dengan kriteria sangat baik.

\section{Daftar Pustaka}

Andersen, dalam Modul Pengembangan Perangkat Penilaian Afektif, Tim Penyusun, Direktorat pembinaan Sekolah Menengah Atas (Depdiknas, 2008)

Amir M. Taufiq, Inovasi Pendidikan Melalui Problem Based Learning: Bagaimana Pendidik Memberdayakan Guru di Era Pengetahuan (Jakarta: Kencana, 2009)

Buchori Muchtar, Pendidikan Antisipatoris (Yogyakarta: Kanisius, 2001) 
Danim Sudarwan, Inovasi Pendidikan dalam Upaya Peningkatan Profesionalisasi Tenaga Kependidikan (Bandung: Pustaka Setia, 2002)

Elaine B. Johnson, Contextual Teaching And Learning: Menjadikan Kegiatan Belajar dan Mengajar Mengasyikkan dan Bermakna, Terj. Ibnu Setiawan (Bandung: MLC, 2006)

Hummel Charles, Education Today for the World of Tomorrow (Paris Unesco, 1977)

Hasbullah, dasar-dasar ilmu pendidikan (Jakarta: RajaGrafindo Persada, 2006)

L.G. Widja, Pengantar Ilmu Sejarah: Sejarah dalam Perspektif Pendidikan (Semarang: Satya Wacana, 1989)

Lewin dalam Andersen, 1980, dalam Modul Pengembangan Perangkat Penilaian Afektif, Tim Penyusun, Direktorat pembinaan Sekolah Menengah Atas (Depdiknas, 2008)

Pribadi Sikun, Peranan Filsafat Pendidikan (Bandung: FIP IKIP, 1971)

Pupuh Fathurrahman dan M. Sobry Sutikno, Strategi Belajar Mengajar (Bandung: Remaja Rosda Karya, 2004)

Purwanto Ngalim, Prinsip-prinsip dan Evaluasi Pembelajaran, (Bandung: Remaja Rosda Karya, 2006)

Syah Muhibbin, Psikologi Pelajar (Jakarta: Logos Wacana Ilmu, 2002) Suryasubroto, Manajemen Pendidikan Di Sekolah (Jakarta: Rineka Cipta, 1997) 